Biografistyka Pedagogiczna

Rok 1 (2016) nr 1

ISSN 2543-6112; e-ISSN 2543-7399

DOI: $10.36578 /$ BP.2016.01.16

Małgorzata Kutyła*

\title{
Przemiany społeczności lokalnej - postęp czy regres społeczny?
}

\section{Transformation of a Local Community: Social Progress or Regress?}

\begin{abstract}
A rather quiet life of the inhabitants of Machów, a small traditional village, located in the district of Tarnobrzeg, was brutally interrupted in the early fifties of the last century. Deposits of sulfur were discovered in the village. As a result, its inhabitants were subjected to the process of resettlement. Although in the initial phase Machów's inhabitants pposed this decision, eventually they were obliged to change their place of residence. The Narrator, then a 14-year-old boy settled with his parents and siblings in one of the village closest to Machów "to be as close to Machów as possible" as his father claimed. The new place did not arouse the Narrator's enthusiasm. According to his report he felt like a stranger in the new environment, as he recalled, "it was impenetrable, people were so resentful." As a grown man, after graduation, he began his career in the sulfur mine and processing plant. Although in the popular opinion the mine transformed the lives of many inhabitants of the surrounding villages, Narrator personally does not see this change as a social progress.
\end{abstract}

Keywords: local community, social change, sulphur, resettlement, Machów

* Małgorzata Kutyła - dr, adiunkt w Akademii Ignatianum w Krakowie, malgorzata.kutyla @ignatianum.edu 


\section{Wprowadzenie}

Życie ludzkie toczy się w nieustannym ruchu i podlega ciągłym zmianom. Najczęściej zmiana społeczna jest postrzegana jako przejście z jednego ładu społecznego do ładu innego typu. Piotr Sztompka definiuje pojęcie zmiany społecznej jako „różnicę między stanem systemu społecznego (grupy, organizacji) w jednym momencie czasu i stanem tego samego systemu w innym momencie czasu"1. A zatem najważniejszymi kategoriami tak rozumianej zmiany społecznej są trzy elementy: „różnica”, „czas” oraz „system”. W tym kontekście zmiana społeczna może zatem być rozumiana jako zmiana zachodząca wewnątrz systemu bądź też obejmująca go w całości. W życiu społecznym zmiany mogą mieć charakter cząstkowy, dlatego też w konsekwencji nie przyczyniają się do zupełnych przeobrażeń całego systemu. W innych okolicznościach zmiana może objąć wszystkie składniki systemu, w efekcie doprowadzając do zupełnej przemiany. W tej sytuacji dokonująca się transformacja każe postrzegać nowy system jako zasadniczo różniący się od poprzedniego ${ }^{2}$. Mark Granovetter podkreśla, że w systemach społecznych dość często można zaobserwować specyficzne „progi graniczne”, po przekroczeniu których zarówno siła, jak i natężenie zmian cząstkowych mogą doprowadzić do przeobrażenia systemu, w konsekwencji przyczyniając się do ilościowej i jakościowej innowacji ${ }^{3}$. Robert Nisbet, mówiąc o zmianie, odnosi ten zwrot

do następstwa różnic w czasie niektórych społecznych stosunków, norm, ról, statusów czy struktur takich jak rodzina, Kościół, naród, własność, rola kobiety, status ojca czy społeczność wioskowa. Każda z tych rzeczy jest społeczna w tym sensie, że wywodzi się ze społecznych raczej aniżeli biologicznych sił, z symbolicznej interakcji - całościowego, kompleksowego procesu, który nazywamy socjalizacją ${ }^{4}$.

Zmiana społeczna bywa utożsamiana z postępem społecznym. Zbigniew Danielewicz stwierdza, że „idea postępu niesie ze sobą wizję rozwijającego się powoli, stopniowo i nieprzerwanie, kumulatywnego postępu rasy ludzkiej w czasie linearnym"5.

1 P. Sztompka, Socjologia. Analiza społeczeństwa, Kraków 2012, s. 495.

2 P. Sztompka, Socjologia zmian społecznych, Kraków 2005, s. 20-21.

3 Tamże, s. 22.

4 P. Starosta, Koncepcje zmiany wiejskiej społeczności w tradycji socjologii polskiej, w: Społeczności lokalne. Teraźniejszość i przyszłość, red. B. Jałowiecki, K. Z. Sowa, P. Dudkiewicz, Warszawa 1989, s. 147.

5 Z. Danielewicz, Idea postępu w kulturze Europy. Od narodzin do dzisiejszego kryzysu, Kosza$\operatorname{lin} 2015$, s. 9. 
Każde ludzie działanie jest zatem wyposażone w sens oraz posiada jakąś logikę, które można ująć w określonym schemacie. W konsekwencji jawi się ono w kategoriach postępu, który zmierza do coraz doskonalszych form życia jednostkowego i społecznego. Aby jednak zmiana uzyskała kwalifikację postępu, musi zostać przedmiotem pozytywnej oceny w świadomości jednostek i grup. To, jest uznane co za postępowe przez określone grupy lub jednostki, w odczuciu innych może być postrzegane jako regres. Postępowość jest zatem zawsze zrelatywizowana.

Celem artykułu jest próba znalezienia odpowiedzi na pytanie, czy zmiany zachodzące w społecznościach lokalnych należy rozpatrywać w kategorii postępu czy regresu społecznego. Podstawą analizy jest narracja, jakiej wysłuchałam w związku z prowadzeniem badań wśród osób pochodzących z Machowa, miejscowości, na terenie której odkryto złoża siarki ${ }^{7}$. Badania zostały przeprowadzone w 2014 r. z osobami przesiedlonymi z tej miejscowości. Na podstawie wywiadu narracyjnego w oparciu o technikę squin, czyli pojedynczego pytania wywołującego narrację. Mój Narrator, obecnie 69-letni mężczyzna, urodził się i mieszkał wraz z rodzicami i rodzeństwem w Machowie do 14. roku życia. W efekcie procesu przesiedlenia zamieszkał wraz z rodziną w miejscowości Baranów Sandomierski. Narrator nie identyfikuje się z nowym miejscem zamieszkania, czuje się w nim wyobcowany, jak sam stwierdza: „zmiana środowiska źle na mnie wpłynęła, na mój start społeczny". Po ukończeniu liceum w Tarnobrzegu, studiował na Politechnice Śląskiej. Po studiach wraz z małżonką powrócił w rodzinne strony i rozpoczął pracę zawodową w przemyśle siarkowym.

\section{Społeczność lokalna}

Tradycyjną społeczność wiejską cechowała zachowawczość i orientacja przeszłościowa. Solidarność wszystkich mieszkańców wsi miała swoje uzasadnienie nie tylko z uwagi na fakt gospodarki naturalnej, ale również swoistego zamkniętego charakteru, który obejmował prawie wszystkie funkcje życia zbiorowego, zamieszkałych na jej terenie

6 P. Sztompka, Socjologia. Analiza, s. 499-500.

7 Machów, nieistniejącą obecnie miejscowość, była zlokalizowana na terenie powiatu tarnobrzeskiego, w północnej części województwa rzeszowskiego. Na początku lat pięćdziesiątych ubiegłego stulecia na terenie Machowa odkryto złoża siarki. W 1970 r. ostatni mieszkaniec opuścił tę miejscowość. Nazwę Machów przejęła Kopalnia. Jej funkcjonowanie zakończyło się na początku lat dziewięćdziesiątych, zaś na części wyrobiska utworzono sztuczne jezioro. D. Kozioł, Zanim przyszła siarka, „Tarnobrzeskie Zeszyty Historyczne”, 27 (20052006) s. 60-61. 
mieszkańców ${ }^{8}$. Zdaniem Izabeli Bukraby-Rylskiej wymiary wiejskiej społeczności odnoszą się do kilku kwestii. Pierwsza z nich dotyczyła zjawiska wiejskiego współdziałania. Jedność i spoistość wsi mieściła się w ramach solidarności sąsiedzkiej i wioskowej. Pomoc sąsiedzka była podejmowana zarówno w warunkach zwykłych (prace sezonowe, inwestycyjne, obrzędowe), jak i w wypadkach szczególnych, np. klęski żywiołowej. Odmienną kwestię stanowiła uprawa ziemi (trójpolówka), która w konsekwencji wymuszała równoczesne realizowanie kolejnych czynności gospodarczych. Wzajemna pomoc mieszkańców wiejskiej wspólnoty, ich kooperacja była nie tylko efektem utrzymującej się solidarności grupy, lecz również konsekwencją zewnętrznych nacisków⿳9 Ważną społecznie formą podejmowanej przez mieszkańców działalności wsi był wzajemny odrobek. Najczęściej bogaci gospodarze wykonywali określone czynności gospodarskie celem pozyskania siły roboczej wśród biedniejszego sąsiedztwa. Przestrzeń wiejskiej społeczności była również terenem zróżnicowanych zależności, wynikających z podziału pracy (odbywające się na zasadzie dzierżawy lub odrobku bądź prowadzeniu domu). W konsekwencji wyspecjalizowana działalność gospodarcza wymuszała powoływanie różnego rodzaju spółek producenckich, spedycyjnych, a także ubezpieczeniowych. Szczególnym wymiarem tego elementu życia na wsi był samorzą ${ }^{10}$. Funkcja samorządu, jak podkreśla Izabela Bukraba-Rylska, łączyła się z funkcją mediatora między światem lokalnym a światem globalnym. Od osób zaangażowanych w funkcjonowanie samorządu wymagano, aby były bądź stawały się lokalnymi autorytetami. Ostatni wymiar zbiorowego życia wsi dotyczył sfery świadomościowej. Kształtowały ją, zdaniem Bukraby-Rylskiej, tożsamość lokalna oraz mit grupowej wartości. Szczególnie akcentowany mit grupowej wartości, podkreślał wyjątkowość własnej grupy, i jednocześnie uzasadniał podział na „swoich” i „obcych” oraz przywiązanie do zajmowanego terytorium ${ }^{11}$. Tradycyjna społeczność lokalna była zatem kształtowana poprzez silne zakorzenienie, identyfikację członków zbiorowości zlokalizowanej w określonej przestrzeni. Obszar wioskowej społeczności był wyznaczony poprzez sieć relacji międzyludzkich oraz stowarzyszeniowych.

8 S. Czarnowski, Podłoże ruchu chłopskiego, w: Socjologia wsi i rolnictwa. Wybór tekstów, red. J. Styk, Lublin 1987, s. 35.

9 I. Bukraba-Rylska, Socjologia wsi polskiej, Warszawa 2013, s. 456.

10 Tamże, s. 457.

11 Tamże, s. 458. 
Zdaniem Pawła Starosty można wyróżnić trzy koncepcje teoretyczne: zmiany kulturowej, zmiany industrialnej, zmiany instytucjonalnej, przy pomocy których podejmowano próby wyjaśnienia przyczyn, mechanizmów oraz konsekwencji zmian zachodzących w społecznościach lokalnych ${ }^{12}$. Bukraba-Rylska w nawiązaniu do typologii Starosty zakłada, że w każdym z trzech modeli zmiany społecznej mamy do czynienia z kolejnymi etapami przeobrażeń zachodzących w społecznościach lokalnych. Pierwszy z nich określa jako „stan pierwotnej integracji układu”, drugi - procesem „dezintegracji początkowego porządku", natomiast trzeci - reintegracją, co oznacza, że w konsekwencji zachodzących zmian ponownie tworzy się nowy ład społeczny ${ }^{13}$.

Koncepcja zmiany kulturowej jest reprezentowana przez Floriana Znanieckiego, Williama Thomasa, Józefa Chałasińskiego, Eugenię Jagiełło-Łysową, Marię Wieruszewską, Włodzimierza Wincławskiego oraz Włodzimierza Pawluczuka. W myśl tej koncepcji wspólnota wioskowa była podstawowym elementem struktury społeczno-przestrzennej, w której jednostka miała poczucie pełnoprawnej przynależności i aktywności. Uczestniczyła w życiu gminy i parafii, aczkolwiek w sposób bierny. Trwanie oraz pewna powszechna zgoda między członkami zbiorowości były konsekwencją jedności postaw i systemu wartości społecznych. Społeczne uznanie jednostka osiągała poprzez takie formy zachowania, które były akceptowane poprzez innych uczestników zbiorowości. W konsekwencji poprzez kontrolę społeczną, wychowanie i socjalizację w społeczności lokalnej osiągana była zbieżność postaw z wartościami. Dezorganizacja środowiska lokalnego miała swoje miejsce wówczas, gdy dokonywał się rozpad wspólnego systemu wartości, gdy jej członkowie przyjmowali niestałe postawy wobec społecznych zdarzeń ${ }^{14}$. Wyłaniające się społeczności lokalne nowego typu były zintegrowane z całym narodem.

Koncepcja zmiany industrialnej jest reprezentowana przez Jana Turowskiego. Główne założenia tej koncepcji koncentrują się wokół dezintegracji społeczności tradycyjnej i reintegracji społeczności nowego typu ${ }^{15}$. Przyczyny rozpadu tradycyjnych środowisk lokalnych upatruje w rozwoju ośrodków przemysłowych oraz rozwoju kapitalizmu na ziemiach polskich. Czynniki zmiany w konsekwencji przeobrażały

12 P. Starosta, Koncepcje zmiany wiejskiej społeczności, s. 150.

13 I. Bukraba-Rylska, Socjologia wsi polskiej, s. 459.

14 P. Starosta, Koncepcje zmiany wiejskiej społeczności, s. 161.

15 Tamże, s. 161. 
dotychczasowy system wartościowania, zmieniały kryteria oceny oraz wzory obyczajowe. Zdaniem Turowskiego proces dezintegracji środowisk lokalnych przechodził kolejne etapy. W pierwszym z nich następuje oswojenie ludności wiejskiej z nowym systemem gospodarowania opartym na gospodarce towarowo-pieniężnej i w efekcie przełamujących izolację zbiorowości wioskowej; nowe narzędzia produkcji i metody gospodarowania oraz migracje. Praca i kontakty z ośrodkami zlokalizowanymi poza obszarem wiejskim rozpoczynały proces rozsadzania starego lokalno-centrycznego uwarstwienia wewnątrz społeczności lokalnej. Kolejny etap dezintegracji środowisk lokalnych przypada na lata dwudzieste ubiegłego wieku. Uzupełnienie czynników zmiany społecznej stanowią w opinii Turowskiego procesy związane z polaryzacją społeczną oraz konfliktami klasowymi; reformę rolną wraz z parcelacją części majątków oraz postępujące dążenia emancypacyjne młodzieży wiejskiej ${ }^{16}$. Trzeci etap dezintegracji następuje po drugiej wojnie światowej. Pojawiło się wiele nowych czynników, które w efekcie wyparły elementy tradycyjnej wiejskiej społeczności lokalnej (likwidację wielkiej własności rolnej, odejście wsi od folwarku, przemieszczanie się ludności na ziemie zachodnie oraz północne, odpływ ludności ze wsi do miasta). Pod wpływem kontaktów z nową przestrzenią, jaką jest miasto, napływały nowe wzory życia i postępowania, obyczaje, wartości i poglądy. Społeczność wioskowa ulega przeobrażeniu ze względnie jednorodnej w zróżnicowaną zbiorowość. W rezultacie zaczęły zanikać dawne zależności funkcjonalno-strukturalne, na których opierała się więź społeczna. Zanikały tradycyjne funkcje, jakie pełniła wspólnota wioskowa, słabła więź sąsiedzka. Nie oznacza to jednak, że proces dezintegracji jest procesem zakończonym, ponieważ w tychże społecznościach, zdaniem Turowskiego, istnieje wiele elementów charakterystycznych dla tradycyjnej społeczności lokalnej. Równocześnie wraz z zanikaniem tradycyjnej społeczności lokalnej zachodzą procesy związane z powstawaniem nowych form integracji w środowiskach wiejskich. Stanowią one pokłosie zachodzących zmian społecznych, u podstaw których znajduje się industrializacja, profesjonalizacja pracy oraz społeczny podział pracy ${ }^{17}$.

W koncepcji zmiany instytucjonalnej (Dyzma Gałaj, Wacław Piotrowski, Piotr Kryczka, Barbara Olszewska-Dyoniziak) zakłada się, iż społeczność wioskowa kreowała instytucje lokalne w sposób samodzielny. Powyższy proces był możliwy z uwagi na fakt, że ludność wiejska przez długi czas pozostawała poza regularnym oddziały-

16 Tamże, s. $162-163$.

17 Tamże, s. 163-165. 
waniem państwa jako instytucji. Wskazana okoliczność skutkowała wykreowaniem wśród mieszkańców określonej świadomości społecznej oraz norm społecznych. Te aspekty życia społecznego powodowały dość silną integrację o charakterze funkcjonalnym, kulturowym oraz komunikacyjnym. Zmiany w społecznościach lokalnych dokonują się w efekcie przenikania na te tereny formalnych struktur państwowych, które w efekcie inspirowały i zaspokajały nowe potrzeby. Natomiast w dłuższej perspektywie powodowały różnicowanie się zarówno interesów, jak i postaw jednostek. Ponadto w rezultacie transferu instytucji formalnych na teren społeczności wioskowej nastąpiło rozbicie wioskowych ram życia społecznego. Przedstawiciele tej koncepcji podkreślają jednocześnie, że przeobrażenia zachodzące zarówno w tradycyjne, jak i „nowe” elementy życia społecznego zostają ostatecznie wkomponowane w sposób pozwalający zachować ciągłość istniejącej zbiorowości. Nasilenie formalizacji i instytucjonalizacji życia w społecznościach wioskowych nastąpiło po drugiej wojnie światowej ${ }^{18}$.

\section{„Machów, był po prostu super"}

Machów, niewielka wioska, jak stwierdza Narrator, „było tam 200 i coś numerów, takich rodzin". Na początku lat pięćdziesiątych ubiegłego stulecia miejscowość została poddana radykalnej zmianie społecznej. Na terenie tej wioski w 1953 r. prof. Stanisław Pawłowski odkrył złoża siarki. Z opowieści Narratora wynika, że życie spokojnej, opartej na zasadach pokrewieństwa i sąsiedztwa wioski uległo modyfikacji. Zmiany zachodzące w społeczności były nie do uniknięcia, zwłaszcza gdy pojawili się tzw. wiertacze. Było to nowe wydarzenie w życiu machowiaków. Z opowieści Narratora nie wynika, aby ich obecność wzbudziła negatywne postawy, odczucia wśród mieszkańców wioski. Wnieśli oni natomiast pewne nowe wartości w życie Narratora, z uwagi na fakt zamieszkania w jego rodzinnym domu. Jak sam wspomina, zostali zakwaterowani „w takim małym pokoiku [...] i wnieśli do tego naszego domu tę Warszawę". Wspólne pomieszkiwanie z kierownikiem wierceń, geologiem i, jak wspomina Narrator, „chyba technologiem” wzbudziło zainteresowanie i ciekawość dorastającego chłopca, „byłem ciekawy, pchałem się do tego pokoiku, tam do nich, a mama bez przerwy mnie tam przeganiała [...], a ja lubiłem z nimi przebywać". Ten pokój we wspomnieniach Narratora jawi się jako tajemnicza przestrzeń, w której działy się rzeczy niezwykłe, nowe, jemu wcześniej nieznane. Mają one przede wszystkim charakter edukacyjny, związany z czytaniem

18 Tamże, s. 167-170. 
książek, opowiadaniem przeczytanych treści oraz nauką „dobrych manier”. Narrator przywołuje zdarzenie związane z wizytą złożoną kierownikowi wierceń przez jednego z mieszkańców wsi. Jej celem była potrzeba nauczenia syna, wówczas licealisty, „dobrych manier [...], kulturalnego zachowania się przy stole, jak ma się kłaniać”. W efekcie, jak wspomina po latach Narrator, „do dziś właśnie tak się kłania, jak go nauczył ten kierownik". Szczególnie ważnym momentem w życiu Narratora był wyjazd do Warszawy, zaproponowany przez jednego z pracowników (kierowcę ciężarówki; byłego pilota z czasów drugiej wojny). Wspomina to: „mama myślała, że to żart, a ja się z nim umówiłem rano, raniutko o 5. już byłem ubrany w takie ubranie od komunii, pamiętam, takie buty miałem z cholewkami". W życiu chłopca był to pierwszy kontakt ze światem zewnętrznym, innym światem, z którym wiążą się pozytywne wspomnienia. Pobyt w Warszawie stał się również powodem szczególnej dumy. Chłopiec miał bowiem świadomość, że jest pierwszym wśród swoich rówieśników, który wykazał się tak dużą mobilnością, możliwością obcowania z innym, nieznanym, aczkolwiek ważnym miejscem. Jak stwierdza,

[...] taki to był kontakt z obcym innym światem, takiego małego dziecka [...] jak ja pojechałem do Warszawy to ja przebiłem wszystkich (uczniów w szkole) najdalej i stolica także i to był plus.

Ponadto w swojej opowieści Narrator dostrzega również materialne znaczenie obecności wiertaczy w Machowie. Wspomina o swoim ojcu, który świadczył odpłatną pracę na rzecz wiertaczy. Zmiany, jakie zachodzą w Machowie wskutek obecności wiertaczy, na tym etapie miały pozytywny oddźwięk. Wspólna koegzystencja przynosiła wiele nowych doświadczeń.

Trwające na terenie Machowa prace przyniosły określone rezultaty. „Pewnego razu jak wspomina Narrator - ten pan kierownik z wierceń przynosi do nas takie kryształy siarki, takie luźne, nie były kruche tylko były takie twarde jak złoto". Wśród mieszkańców wsi pojawiły się informacje, że „na złocie leży ten Machów”. Efekty prac wiertaczy spotykały się raczej z pozytywnym przyjęciem wśród mieszkańców. Natomiast dla Narratora był to pierwszy moment, w którym dostrzegł negatywne konsekwencje prowadzonych prac. Tym samym można wyodrębnić kolejny etap związany z obecnością wiertaczy w środowisku lokalnym. Narrator z przykrością argumentuje, że rezultaty prac stały się niekorzystne zwłaszcza dla środowiska naturalnego:

jak wiercili te otwory [...] i zrobili takie próbne odwodnienie tego złoża [...] jak spuścili tę wodę do jeziora machowskiego to tam wszystkie ryby wytruli, wszystko. 
Po tych doświadczeniach mieszkańcy Machowa, jak wynika z opowieści Narratora, zaczęli dostrzegać coś niepokojącego. Rozpoczynającym się przeobrażeniom społecznym próbowali przeciwdziałać, gdyż występujące zdarzenia były jaskrawo sprzeczne z tradycjami społeczności. Zatem w sytuacji, gdy dezorganizacja społeczności lokalnej stała się faktem, machowiacy podejmowali spontaniczne dążenia celem zahamowania tego procesu. Wśród mieszkańców społeczności wioskowej ograniczeniu uległo poczucie bezpieczeństwa i stabilizacji. Fakt pewnej nieprzejrzystości związanej z przyszłym funkcjonowaniem Machowa był dodatkowo spotęgowany informacją o przesiedleniu. Machowiacy zostali poinformowani o powstającym zakładzie przemysłowym oraz o konieczności przesiedlenia. Mimo ich sprzeciwu, najczęściej wyrażanego jako brak woli do opuszczenia miejsca z uwagi na „zżycie się z tym terenem i z parafią", działania wynikające z konieczności opuszczenia Machowa były realizowane dość szybko. Jak wspomina Narrator,

[...] ludzie zaczynali spotykać się po domach [...] i pamiętam jak ciocia Marysia opowiadała, że do tej firmy właśnie przyjechał przedstawiciel państwowy taki wyższej rangi i zebranie Machowiaków było i powiedział, że tutaj będzie kopalnia siarki rudy siarkowej, a Wasze miejsce jest w Ustrzykach Dolnych tam będziecie mieszkać.

Mieszkańcy obawiali się „nowego miejsca”, nie tylko dlatego, że w nowych warunkach zakres ich działalności stał się ograniczony, lecz przede wszystkim stanęli przed niemożnością kontrolowania swojej przyszłości. Obawy związane z tym terenem, aczkolwiek uzasadnione, spowodowały, że mieszkańcy rozpoczęli samodzielnie poszukiwać nowego miejsca zamieszkania. Część z nich podejmowała decyzję o zakupie ziemi w pobliżu Machowa, by - jak twierdził ojciec Narratora - „być jak najbliżej Machowa”. W konsekwencji, przesiedlenie do Ustrzyk Dolnych zostało zaniechane. Rozczłonkowani mieszkańcy Machowa zostali przesiedleni na tak zwane grunty państwowe, pozostałe po wielkich majątkach. W Baranowie Sandomierskim zasiedlano obszary znacjonalizowane, należące przed drugą wojną światową do hrabiego Dolańskiego, w Zbydniowie tereny należące do hrabiego Horodyńskiego. Część mieszkańców osiedliła się w Wymysłowie oraz w Tuszynie. Pozostała grupa mieszkańców, jak stwierdza Narrator, „[...] otrzymywała pieniądze z założeniem, że zamieszkają w blokach”"19. Rozpoczęty proces niesie z sobą rozbicie społeczności lokalnej.

19 Wraz z postępującymi pracami nad budową kopalni na terenie Machowa, rozbudowuje się miasto Tarnobrzeg, położone w odległości około $2 \mathrm{~km}$ od Machowa. 


\section{Zamiast Machowa}

Równocześnie z zakończeniem prac w Machowie i procesem przesiedlenia rozpoczęła się budowa kopalni oraz przeobrażenia miasta Tarnobrzeg ${ }^{20}$. Jak wspomina Narrator, „zaczynają budować bloki w Tarnobrzegu”. W jego refleksji stały się one synonimem rozwoju miasta. W efekcie przesiedlenia część mieszkańców Machowa zamieszkała również w Tarnobrzegu. W rozwijającym się mieście osiedlali się przede wszystkim ludzie napływowi z różnych części kraju. O atrakcyjności miasta świadczyły przede wszystkim względy materialne, związane z otrzymaniem pracy oraz mieszkania. Kilkakrotnie w swojej opowieści Narrator podkreślał znaczenie „siarki” w przeobrażeniach, jakim podlegały miasto Tarnobrzeg oraz jego okolice. Korzyści płynące z pracy zawodowej w kopalni, zdaniem Narratora częściej dostrzegali młodzi mieszkańcy Machowa oraz sąsiednich miejscowości. Narrator jednocześnie sugeruje, że młodzi mieli inny stosunek do pracy najemnej. Młode pokolenie w nowo organizującym się miejscu pracy dostrzegało szanse na lepsze życie. Tym samym w naturalny sposób ludzie młodzi rezygnowali z pracy na roli, gdyż „praca w siarce” dawała inne możliwości zarobkowania. Jak wspomina Narrator, „młłodym nie uśmiechała się praca na roli”. Kontakt ludzi młodych ze światem zewnętrznym przyczyniał się do rozwijania nowych postaw, a także wnoszenia do społeczności nowych wartości. Możliwość aktywności zawodowej w kopalni po raz pierwszy stwarzała możliwość zmiany swojego miejsca w strukturze społecznej. Wchodzenie ludności wiejskiej w obszar życia zawodowego rozszerzało zasięg ich kontaktów. W rezultacie zupełnej likwidacji ulegała dawna izolacja społeczności wioskowej. Nie oznacza to jednak, że starsza generacja nie podejmowała pracy w kopalni. Narratorowi trudno jednoznacznie określić motywy, jakie towarzyszyły takim decyzjom, jak stwierdził: „wszyscy tam się pchali”. Podjęcie pracy w kopalni mogło być warunkowane trudną sytuacją materialną rodzin. W tym zakładzie podjął pracę również ojciec Nar-

20 Tarnobrzeg miasto założone w 1593 r. przez rodzinę Tarnowskich. W okresie dwudziestolecia międzywojennego miasto powiatowe, z przewagą mieszkańców wyznania mojżeszowego. W latach 1975-1998 było stolicą województwa. Obecnie miasto powiatowe, zlokalizowane na terenie województwa podkarpackiego. Miasto, które od chwili swojego powstania, do pierwszej połowy xX w. było niemal niezmiennym organizmem. Odkrycie w 1953 r. złóż siarki i w konsekwencji rozwój przemysłu siarkowego zadecydowało o dynamicznym rozwoju przestrzennym, infrastruktury oraz sytuacji demograficznej. Spowodowało przede wszystkim migrację młodych ludzi z różnych stron Polski, którzy stawali się nowymi mieszkańcami miasta. Po 1989 r., wskutek załamania się koniunktury na siarkę, na światowych rynkach, Tarnobrzeg został pozbawiony znaczącego czynnika służącego rozwojowi miasta. Tarnobrzeg. Dzieje miasta 1939-1999, red. F. Kiryk, A. Wójcik-Łużycki, Tarnobrzeg 2010, s. 5-6. 
ratora. Aczkolwiek, jak wspomina, „on nigdy nie chwalił tej pracy zawodowej, tak jakby pracował z przymusu". Najprawdopodobniej taka postawa wynikała z charakteru pracy najemnej. Praca rolnika, jak podkreślał Narrator, jest zajęciem trudnym: „jest to praca po prostu herosów". Daje jednakże możliwość uporządkowanego i wolnego działania przy współudziale sił przyrody. Udział ludności wiejskiej w życiu ekonomicznej cechowała raczej bierność. Ci mieszkańcy społeczności lokalnych byli dobrze przygotowani, jak stwierdza Florian Znaniecki do starych warunków lokalnej ekonomii rolnej. Natomiast w sytuacji przeobrażeń świata zewnętrznego jednostka stawała się bezsilna, osamotniona, nieświadoma tego co się dzieje $e^{21}$.

\section{Podsumowanie}

Procesy modernizacji, które przybrały postać industrializacji, doprowadziły do zaniku odrębnego systemu życia wiejskiego. W rezultacie zanikał specyficzny obraz społeczności lokalnych, który cechowały wspólne normy, zasady, a także posługiwanie się określonymi kategoriami „swój” i „obcy”. Postępujący proces industrializacji eliminował te elementy życia wspólnoty wioskowej, które nadawały jej charakterystyczny wymiar: źródło utrzymania ludności, więzi będące podstawą integracji jednostek, instytucje życia zbiorowego, specyficzna mentalność. W społeczności machowskiej rolnictwo stanowiło dominujące źródło utrzymania ludności. Więzi społeczne kształtowały się w efekcie koordynacji i uporządkowanego systemu życia wsi, zachodzącego między gospodarstwem chłopskim, rodziną a sąsiedztwem. Instytucje życia społecznego były kreowane częściej przez współpracę, wzajemną pomoc, aniżeli konkurencję czy współzawodnictwo. Specyficzna mentalność stanowiła pokłosie niechęci do zmiany, wyrażała się skłonnością do akceptacji własnej sytuacji. Z opowieści Narratora wynika, że w efekcie przeobrażeń struktury społecznej został rozerwany homogeniczny, partykularny charakter dawnej organizacji społecznej Machowa. Niejednokrotnie wskazywał na istotę miejsca, w którym się urodził i wychowywał do 14 roku życia. W jego narracji Machów jawi się jako miejsce szczególnie ważne w jego biografii. Podkreśla swój związek z Machowem, artykułując wyjątkowość tego miejsca:

dla mnie Machów i okolice żadnych tajemnic nie miały [...], każdą dziurę, każdy kamień pamiętam, taką wierzbę na przykład, gdzie miały gniazda dudki, zamknę oczy, wszystko wiem, po prostu [...], smak owoców jeszcze pamiętam.

21 W. I. Thomas, F. Znaniecki, Chłop polski w Europie i Ameryce, t. 1, Warszawa 1978, s. 124. 
Z jego perspektywy, życiowych satysfakcji Machów symbolizował poczucie zakorzenienia, bezpieczeństwa, przewidywalności i stabilizacji. Środowisko pochodzenia było ważnym miejscem edukacji, również w momencie zetknięcia się z Innymi. W efekcie tego spotkania odkrył w sobie wrażliwość, potrzebę doskonalenia własnej osobowości. Zmiana miejsca zamieszkania nie wzbudziła u Narratora entuzjazmu. Z perspektywy czasu uważa, że nowe środowisko życia wykształciło w nim chęć izolowania się. Z jego punktu widzenia postępująca industrializacja przyczyniła się do zaniku więzi, które kształtowały społeczność machowską. W rezultacie ten proces oznaczał dla Narratora utratę jakości życia i sprzeniewierzenie się naturze ludzkiej. Mimo iż jako dorosły mężczyzna podejmuje działalność zawodową w kopalni, nie postrzega jej w kategorii awansu społecznego, wręcz przeciwnie - jak sam stwierdza - „czułem, że to jakieś nieporozumienie cała ta kopalnia". W wymiarze indywidualnym nie dostrzega pozytywnych zmian w związku z rozwojem przemysłu siarkowego. W tym przypadku zdecydowanie częściej akcentuje regres, który najczęściej przejawia się w postaci dewastacji naturalnego środowiska oraz zanikania tradycyjnych, wspólnotowych więzi międzyludzkich.

Docenia pozytywne oddziaływanie kopalni na lokalną ludność oraz miasto Tarnobrzeg, aczkolwiek w jego narracji raczej śladowo pojawia się kwestia związana z tym. Proces industrializacji przyczynił się do zmiany położenia jednostek w strukturze społecznej, stwarzał możliwości zatrudnienia, w ich rezultacie wpłynął na poprawę sytuacji materialnej jednostek, w konsekwencji zwiększał udział ludności w konsumpcji. Z opowieści Narratora wynika, że w wymiarze społecznym dało się zauważyć postęp.

Streszczenie: Raczej spokojne życie mieszkańców Machowa, małej tradycyjnej wsi, położonej w powiecie tarnobrzeskim zostało brutalnie przerwane na początku lat pięćdziesiątych ubiegłego stulecia. Na terenie miejscowości odkryto złoża siarkowe. W konsekwencji jej mieszkańcy zostali poddani procesowi przesiedlenia. Mimo iż w początkowej fazie machowiacy sprzeciwiali się tej decyzji, ostatecznie zostali zobowiązani do zmiany miejsca zamieszkania. Narrator, wówczas 14 letni chłopiec, wraz z rodzicami i rodzeństwem osiedlił się w jednej z najbliżej położonych od Machowa miejscowości, by jak twierdził jego ojciec „być jak najbliżej Machowa”. Nowe miejsce nie wzbudziło u Narratora entuzjazmu. Z jego relacji wynika, iż nowym środowisku czuł się obco, jak wspominał „było ono hermetyczne, ludzie jacyś tacy zawistni”. Jako dorosły mężczyzna, po ukończeniu studiów, rozpoczął pracę zawodową w kombinacie siarkowym. Mimo iż w powszechnej opinii kopalnia przekształciła życie wielu mieszkańców okolicznych wiosek, Narrator osobiście nie postrzega tej zmiany w kategoriach postępu społecznego.

Słowa kluczowe: społeczność lokalna, zmiana społeczna, siarka, przesiedlenie 


\section{Bibliografia}

Bukraba-Rylska I., Socjologia wsi polskiej, Warszawa 2013.

Czarnowski S., Podłoże ruchu chłopskiego, w: Socjologia wsi i rolnictwa. Wybór tekstów, red. J. Styk, Lublin 1987.

Danielewicz Z., Idea postępu w kulturze Europy. Od narodzin do dzisiejszego kryzysu, Koszalin 2015 .

Kiryk F., Wójcik-Łużycki A, Tarnobrzeg Dzieje Miasta 1939-1999, Mielec 2010.

Kozioł D., Zanim przyszła siarka, „Tarnobrzeskie Zeszyty Historyczne”, 27 (2005-2006).

Starosta P., Koncepcje zmiany wiejskiej społeczności w tradycji socjologii polskiej, w: Społeczności lokalne. Teraźniejszość i przyszłość, red. B. Jałowiecki, K. Z. Sowa, P. Dudkiewicz, Warszawa 1989.

Sztompka P., Socjologia zmian społecznych, Kraków 2005.

Sztompka P., Socjologia. Analiza społeczeństwa, Kraków 2012.

Tarnobrzeg. Dzieje miasta 1939-1999, red. F. Kiryk, A. Wójcik-Łużycki, Tarnobrzeg 2010.

Thomas W. I., F. Znaniecki, Chłop polski w Europie i Ameryce, t. 1, Warszawa 1978. 